\title{
Academic Library Administrators' Perceptions of Four Instructional Skills
}

\section{John D. Shank and Nancy H. Dewald}

This study seeks to fill a gap in the literature by examining the perceptions of current administrators toward four domains and their associated skill sets needed to fulfill the library's instructional role. Hundreds of Library Directors/Deans/Associate Deans/Heads in academic libraries of all sizes across the United States were surveyed to determine to what extent they value the skill sets associated with the four selected instructional skill domains: two traditional-teaching and presentation-and two more recently adopted by librarians-instructional design and educational technology. The findings of this research indicate that library administrators value the traditional skill sets more than the newer nontraditional skills. The results and possible implications, as well as directions future studies can take, are discussed.

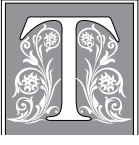

raditionally, academic librarians have tried to integrate themselves into the teaching and learning process on their campuses using existing skill sets in instruction. With the growth of library instruction, the evolution of educational technologies, and the advent of information literacy, the instructional role of the academic library has expanded and, with it, the skills that librarians need. New positions have been developed and existing positions have been redefined to include additional skills. This is reflected in the 2007 Association of College and Research Libraries (ACRL) Environmental Scan's "Top Ten Assumptions for the Future of Academic Libraries and Librarians." ${ }^{1}$
The second assumption was "[t]he skill set for librarians will continue to evolve in response to the changing needs and expectations of the populations they serve, and the professional background of library staff will become increasingly diverse in support of expanded service programs and administrative needs." ${ }^{2}$ Evidence of this is seen in the Blended Librarian Online Community, numbering nearly 5,000 members. ${ }^{3}$ This group is made up largely of librarians interested in enhancing their abilities in instructional design and educational technology.

Academic library administrators are in key positions to influence the future direction of the profession. When a new position is created, or when a librar-

John D. Shank is Instructional Design Librarian and Nancy H. Dewald is Reference Librarian at Penn State Berks; e-mail: jds30@psu.edu and nxd7@psu.edu, respectively. The authors wish to thank Dr. Mary Lou D'Allegro, formerly Senior Director of Planning, Research, and Assessment at Penn State Berks, for her assistance in the survey analysis. (C) John D. Shank and Nancy H. Dewald 
ian seeks training to broaden his or her skill set, the administrator signs off on these changes. This tacitly implies that the administrator values the position's skills. Administrators' perceptions of the importance of instructional skills will affect their decisions about funding and approving new positions or new training for librarians. In terms of the instructional role of the library, changes in the academic library environment have resulted in librarians having not only traditional skills in teaching and presentation, but also adding skills in instructional design and educational technology. However, to what extent do administrators value the new instructional skill sets?

The purpose of this research study is to explore the perceptions of today's library administrative leaders toward four domains with associated skills needed to fulfill the library's instructional role. This will provide baseline information that can be used to begin to frame discussions of how administrator biases are impacting change within the profession. This is important because, by being better informed about current administrators' perceptions, the profession can gain valuable insight into the values of the people in key positions to influence the future direction of the profession.

\section{Research Questions}

This study seeks to fill a gap in the literature with regard to the perceptions of today's library administrators toward the importance of skill sets associated with the four domains needed to fulfill the library's instructional role. This study asked: Given the four selected instructional skill sets, two nontraditional (instructional design and educational technology) and two traditional (presentation and teaching), which skills and related proficiencies do academic library administrators perceive as most important for fulfilling the instructional role of the library? Specifically, to what extent do academic library administrators value the newly adopted skill sets of instructional design and educational technology? To what extent do academic library administrators value the traditional skill sets of presentation and teaching?

\section{Background \& Literature Review}

A number of sources informed the selection of the four domains and the approach to developing the survey instrument. A primary source was the ACRL 2007 "Standards for Proficiencies for Instruction Librarians and Coordinators." This source included detailed information about instructional design, presentation, and teaching skills. ${ }^{4}$ Additionally, studies of instruction courses in graduate Library and Information Science programs have found a significant number emphasizing learning theory and instructional design in addition to teaching and presentation. ${ }^{5}$ Authors in both the United Kingdom ${ }^{6}$ and the United States ${ }^{7}$ have noted the increasing need for educational technology skills for librarians.

To date, there has not been a study that has attempted to ascertain academic library administrators' perceptions of any of the profession's instruction-related skills. However, a number of studies have examined these new skill sets and emerging positions, and library administrators presumably would be aware of such changes in their staff. Some studies have looked at the increasing integration of instructional design or educational technology skills and knowledge into the library profession. ${ }^{8}$ Others have looked at job or positional announcements to identify changes in the profession. ${ }^{9}$ Skill sets in instructional design or development and educational technology are apparent in the position announcements associated with these job titles. ${ }^{10}$ See table 1 for a list of newly emerging positions.

\section{Methods}

This study measured the perceptions of today's library administrators toward the importance of the selected skill sets associated with Instructional Design, Educational Technology, Presentation, 


\begin{tabular}{|l|l|}
\multicolumn{2}{|c|}{$\begin{array}{c}\text { TABLE 1 } \\
\text { Selected Academic Librarian Position Titles for Positions } \\
\text { that Further the Teaching Mission of the Library }\end{array}$} \\
\hline Academic Librarian Position Title & Cited by \\
\hline Academic and Digital Applications Librarian & Allen \\
\hline Distance Learning Librarian & Simmons-Welburn \\
\hline Electronic and Distance Education Librarian & Simmons-Welburn \\
\hline Electronic and Instructional Services Librarian & Goetsch \\
\hline Information Literacy/Instructional Technology Librarian & Allen \\
\hline Instructional Design and Instructor Development Librarian & Allen \\
\hline Instructional Design Librarian & Allen; Goetsch; Shank \\
\hline Instructional Development Librarian & Allen; Simmons-Welburn \\
\hline Instructional Technologist & Simmons-Welburn \\
\hline Instructional Technology Librarian & Allen \\
\hline Technology Instruction Librarian & Allen \\
\hline Technology Training Specialist & Simmons-Welburn \\
\hline Web Manager and Instructional Design Librarian & Allen \\
\hline
\end{tabular}

and Teaching for fulfilling the library's instructional role. The objective was to discover the degree to which current library administrators value the aboveidentified existing (that is, traditional) and newly emerging skills associated with instruction librarians.

\section{Methodology}

A cross-sectional, self-reporting survey instrument was created to achieve the study's objectives, and Institutional Review Board approval with an exemption was sought and received from the investigators' institution. The total population for the study consisted of all U.S. academic library administrators, including Library Directors, Deans, Associate Deans, or Heads from the 3,827 postsecondary degree-granting institutions listed in the "Total number of academic libraries, by level, control of institution, and state: 2008."11 The principal investigators targeted a 95 percent confidence level with a +/- error band of $5 \%$ as our goal, which required our sample population be approximately 350 library administrators.
To identify a sample population from the total population, the investigators decided to draw from the most densely populated areas of the United States. This was done to obtain a large enough sample size. The limitation of this method is that it inadvertently may have created a bias against rural postsecondary institutions. The tool used to select the sample was the National Center for Education Statistics' "Search for Schools, Colleges, and Libraries" site. $^{12}$

The following search criteria were used to create the sample population: postsecondary institutions within a 50mile radius of the 25 largest Metropolitan Statistical Areas (MSAs) in the United States were selected, resulting in a sample population of 866 academic libraries. E-mail addresses for the dean, director, or head library administrator of each institution's library were then identified and collected through staff listing at the identified institutions' library Web sites.

Recipients of the recruitment e-mail were asked to have the person who is ultimately responsible for approving newly created or redefined librarian 
positions fill out the survey, which the investigators assumed would be a top library administrator. This specification was given so that the administrator would not have an instruction librarian fill out the survey. A presurvey e-mail alerting recipients of the survey request was sent a few days ahead in hopes of increasing the response rate. The second e-mail message contained a link to an online "implied informed consent" letter, which contained a link directly to the online survey. The investigators did not have any budget available to offer a reward incentive, so none was offered.

\section{Instrument Design}

The investigators searched and collected approximately 100 instruction-related librarian job advertisements in 2008 from the following sources: IFLA's LibJobs, ${ }^{13}$ Educause's Job Opportunities, ${ }^{14}$ and the ALA JobLIST..$^{15}$ Results from this search and from the literature review were used to identify and select the four core domains needed by librarians for the instruction process: instructional design skills, educational technology skills, presentation skills, and teaching skills.

The two traditional domains selected for this study, presentation and teaching, have been widely recognized as incorporating important skills for instructors for decades. The two newly emerging domains, instructional design and educational technology, have more recently been recognized as including important skills. In the course of conducting the literature review, it became apparent that there is some confusion in the academic library profession about the distinction between instructional design and educational technology. Because there is some ambiguity with these terms in the larger educational community, this study allowed the skills under each domain to frame the definition.

The survey consisted of ten questions with an additional open comments field at the end. The survey was organized into three sections. The first section included four Likert type scale questions. These asked participants to rate the importance, on a scale of 1 (strongly disagree) to 5 (strongly agree), and "not applicable," of the skills associated with instructional design, educational technology, presentation, and teaching (see Appendix A). The second section included one Likert type scale question that asked participants to rank in order (1: least important to 4 : most important) the importance of the four domains (namely, instructional design, educational technology, presentation, and teaching) to future newly created and/or redefined positions in their library. The final section consisted of four free-text questions focused on: listing any additional skill sets related to these domains they would consider critical to their library's instructional process; listing the name of their institution; listing their position title; listing how many years they have worked as a librarian. The final question surveyed the gender of the library administrator.

A draft of the survey instrument was created in July of 2008 and first sent to a dozen local area academic library administrators to check content validity, and changes were made based on their suggestions. The revised survey was piloted in the fall of 2008 to a representative group of academic library administrators within a 30-mile radius of the Philadelphia MSA. The results of this survey were analyzed using Coefficient Alpha calculated in SPSS, which indicated that the survey results were consistent and reliable. Subsequently, no further modifications were deemed necessary, and the same survey was sent to academic library administrators in the other 24 MSAs and the larger radius of the Philadelphia MSA in the spring of 2009.

\section{Results}

Of the 866 academic libraries identified in the targeted MSAs, e-mails for administrators were found for 682, but eight institutions had undeliverable e-mail addresses, leaving 674 Library Directors, Deans, Associate Deans, or Heads of aca- 
demic libraries. Of these, 374 participants clicked through the e-mail link to go to the online survey. From this self-selected group, a total of 316 respondents filled out the survey, giving a response rate of approximately 44 percent. This response rate is consistent with acceptable response rates for surveys administered online. ${ }^{16}$ The final results of the survey were again analyzed in SPSS using Coefficient Alpha, a measure of consistency of responses. A level of .7 or higher is considered good, and the alphas reported for each section and overall were all above .8. Additionally, significance testing was done to determine if there is any significant difference in the opinions of the respondents about the four domains. Using Hotelling's T-square distribution test in SPSS, it was determined that survey results are significant (Composites $=$ Approx. $\mathrm{F}=1491.177$, $\mathrm{df}=3, \mathrm{p}<.001 \&$ Ranks = Approx. $\mathrm{F}=39.756$, $\mathrm{df}=3, \mathrm{p}<.001$ ). Therefore, there are statistically significant differences among the ratings (rankings) with respect to what skills administrative librarians value.

The survey did not require respondents to answer every question; consequently, the numbers of those answering specific questions varied slightly. The first four question sections had 314-316 respondents, the fifth question section had 282-309, and demographic questions and optional comments had various numbers of respondents. Gender of respondents were 191 female $(61 \%)$ and 124 male (39\%). The American Library Association reported in 1999 a ratio among academic library directors of 57 percent female to 43 percent male, ${ }^{17}$ while the Association of Research Libraries reported a 2009-2010 ratio of 60 percent female to 40 percent male library directors, and a ratio of 61 percent female to 39 percent male for associate directors. ${ }^{18}$ The present survey's results are comparable to these ratios. Of the 312 who listed their position title, nearly all were among the targeted group of library administrators, with only one listing "reference librarian." This respondent's survey results were not included because he or she did not match the survey's participant criteria.

Respondents were asked to give their institution name, and 299 did so. Table 2 shows the Carnegie Classifications ${ }^{19}$ of these institutions. Percentages of respondent institutions closely matched the national percentages for Associates and Baccalaureate Colleges-Diverse Fields. The remaining classification percentages of the respondents were not as close a match nationally. Comparing respondents' percentages to the total institutions e-mailed finds strong parallels. If all Baccalaureate Colleges are counted together, the percentages are 20.0 percent (respondents), 19.1 percent (total), and 17.4 percent (Carnegie). So for the first four Carnegie classification institutions, the respondents are fairly representative of the nation as a whole. Other classifications are comparable to the total e-mailed, indicating that the respondent institutions are reflective of those institutions within a 50-mile radius of the top 25 MSAs in the nation. It would be difficult to match all classifications nationally. Of respondents overall, there was greater representation among Master's, Doctoral, and Research institutions than nationally and less representation among Special Focus institutions (arts, business, engineering, faith, health, law, medical, technology, and other) than nationally.

The first four survey questions asked, "When thinking about the necessary or required skills for librarians who participate in the library's instructional process, please rate the importance on a scale of 1 (strongly disagree) to 5 (strongly agree) for each of the following" and included several skills under each of the four domains: instructional design, educational technology, presentation, and teaching. Among the instructional design skills, those skills that referred to theories of instruction and theories of learning, both with specific examples, received overall lower ratings. Fully 95 percent of respondents agreed or strongly agreed to the importance of "Ability to define learning outcomes," 89 percent agreed or strongly agreed to the importance of "Ability to 
create a lesson plan," and 85 percent agreed or strongly agreed to the importance of "Ability to share with colleagues instructional theories and practices." In contrast, only 54 percent and 58 percent, respectively, agreed or strongly agreed to the importance of "Ability to apply theories of instruction" and "Ability to apply theories of learning," and 36 percent and 31 percent, respectively, selected neutral to these questions. See table 3 for details about all of the four domains.
In the area of educational technology skills, the strongest support was for "Ability to integrate appropriate technology" (nearly 99 percent agreed or strongly agreed), "Ability to utilize online/webbased technologies" (97 percent agreed or strongly agreed), and "Ability to adopt emerging instructional technologies (e.g. Web 2.0)" (94 percent agreed or strongly agreed). The lowest support was for "Ability to create multimedia digital learning objects" to which only 66 percent of

\begin{tabular}{|c|c|c|c|c|c|c|}
\hline \multicolumn{7}{|c|}{$\begin{array}{c}\text { TABLE } 2 \\
\text { Carnegie Classifications of Respondent and Total Institutions }\end{array}$} \\
\hline $\begin{array}{l}\text { Carnegie } \\
\text { Classifications* }\end{array}$ & $\begin{array}{l}\text { Respondent } \\
\text { Institutions } \\
\mathbf{N}=299:\end{array}$ & $\begin{array}{l}\text { Respondent } \\
\text { Institution } \\
\text { Percent }\end{array}$ & $\begin{array}{c}\text { Total } \\
\text { Institutions } \\
\text { Emailed } \\
\mathbf{N}=\mathbf{6 8 2} \\
\end{array}$ & $\begin{array}{c}\text { Total } \\
\text { Institutions } \\
\text { Percent }\end{array}$ & $\begin{array}{c}\text { Carnegie } \\
\text { Institutions }\end{array}$ & $\begin{array}{l}\text { Carnegie } \\
\text { Institutions } \\
\text { Percent }\end{array}$ \\
\hline Associate's & 82 & $27.4 \%$ & 186 & $27.3 \%$ & 1212 & $27.7 \%$ \\
\hline $\begin{array}{l}\text { Baccalaureate } \\
\text { Colleges--Arts \& } \\
\text { Sciences }\end{array}$ & 33 & $11.0 \%$ & 60 & $8.8 \%$ & 287 & $6.5 \%$ \\
\hline $\begin{array}{l}\text { Baccalaureate/ } \\
\text { Associate's } \\
\text { Colleges }\end{array}$ & 3 & $1.0 \%$ & 15 & $2.2 \%$ & 120 & $2.7 \%$ \\
\hline $\begin{array}{l}\text { Baccalaureate } \\
\text { Colleges--Diverse } \\
\text { Fields }\end{array}$ & 24 & $8.0 \%$ & 55 & $8.1 \%$ & 360 & $8.2 \%$ \\
\hline $\begin{array}{l}\text { Master's Colleges } \\
\text { and Universities } \\
\text { (smaller programs) }\end{array}$ & 14 & $4.6 \%$ & 30 & $4.4 \%$ & 128 & $2.9 \%$ \\
\hline $\begin{array}{l}\text { Master's Colleges } \\
\text { and Universities } \\
\text { (medium } \\
\text { programs) }\end{array}$ & 27 & $9.0 \%$ & 51 & $7.5 \%$ & 190 & $4.3 \%$ \\
\hline $\begin{array}{l}\text { Master's Colleges } \\
\text { and Universities } \\
\text { (larger programs) }\end{array}$ & 51 & $17.0 \%$ & 113 & $16.6 \%$ & 345 & $7.9 \%$ \\
\hline $\begin{array}{l}\text { Doctoral/Research } \\
\text { Universities }\end{array}$ & 16 & $5.3 \%$ & 39 & $5.7 \%$ & 84 & $1.9 \%$ \\
\hline $\begin{array}{l}\text { Research } \\
\text { Universities (high } \\
\text { research activity) }\end{array}$ & 16 & $5.3 \%$ & 32 & $4.7 \%$ & 103 & $2.3 \%$ \\
\hline $\begin{array}{l}\text { Research } \\
\text { Universities (very } \\
\text { high research } \\
\text { activity) }\end{array}$ & 17 & $5.6 \%$ & 42 & $6.1 \%$ & 96 & $2.2 \%$ \\
\hline $\begin{array}{l}\text { Special Focus } \\
\text { Institutions }{ }^{\dagger}\end{array}$ & 15 & $5.0 \%$ & 45 & $6.6 \%$ & 806 & $18.4 \%$ \\
\hline (Not classified) & 1 & $0.3 \%$ & 14 & $2.0 \%$ & 26 & $0.6 \%$ \\
\hline
\end{tabular}


TABLE 3

When thinking about the necessary or required skills for librarians who participate in the library's instructional process, please rate the importance on a scale of 1 (strongly disagree) to 5 (strongly agree) for each of the following:

\begin{tabular}{|c|c|c|c|c|c|c|c|}
\hline $\begin{array}{l}\text { Top number is the count of } \\
\text { respondents selecting the } \\
\text { option. Bottom \% is percent } \\
\text { of the total respondents } \\
\text { selecting the option. }\end{array}$ & $\begin{array}{l}\text { strongly } \\
\text { disagree }\end{array}$ & disagree & neutral & agree & $\begin{array}{l}\text { strongly } \\
\text { agree }\end{array}$ & N/A & mean \\
\hline \multicolumn{8}{|l|}{ Instructional Design Skills } \\
\hline \multirow{2}{*}{$\begin{array}{l}\text { Ability to define learning } \\
\text { outcomes }\end{array}$} & 4 & 2 & 9 & 91 & 210 & 0 & 4.58 \\
\hline & $1 \%$ & $1 \%$ & $3 \%$ & $29 \%$ & $66 \%$ & $0 \%$ & \\
\hline \multirow[t]{2}{*}{ Ability to create a lesson plan } & 4 & 3 & 25 & 112 & 172 & 0 & 4.42 \\
\hline & $1 \%$ & $1 \%$ & $8 \%$ & $35 \%$ & $54 \%$ & $0 \%$ & \\
\hline \multirow{2}{*}{$\begin{array}{l}\text { Ability to apply theories of } \\
\text { instruction (e.g., Gagne's Nine } \\
\text { Events of Instruction) }\end{array}$} & 4 & 26 & 112 & 116 & 53 & 5 & 3.60 \\
\hline & $1 \%$ & $8 \%$ & $35 \%$ & $37 \%$ & $17 \%$ & $2 \%$ & \\
\hline \multirow{2}{*}{$\begin{array}{l}\text { Ability to apply theories of } \\
\text { learning (e.g., Behaviorism, } \\
\text { Cognitivism, Constructivism) }\end{array}$} & 6 & 25 & 98 & 130 & 55 & 2 & 3.64 \\
\hline & $2 \%$ & $8 \%$ & $31 \%$ & $41 \%$ & $17 \%$ & $1 \%$ & \\
\hline \multirow{2}{*}{$\begin{array}{l}\text { Ability to share with colleagues } \\
\text { instructional theories and } \\
\text { practices }\end{array}$} & 4 & 10 & 33 & 126 & 141 & 0 & 4.24 \\
\hline & $1 \%$ & $3 \%$ & $11 \%$ & $40 \%$ & $45 \%$ & $0 \%$ & \\
\hline \multicolumn{8}{|l|}{ Educational Technology Skills } \\
\hline \multirow{2}{*}{$\begin{array}{l}\text { Ability to adopt emerging } \\
\text { instructional technologies (e.g., } \\
\text { Web 2.0) }\end{array}$} & 1 & 3 & 16 & 120 & 176 & 0 & 4.47 \\
\hline & $0 \%$ & $1 \%$ & $5 \%$ & $38 \%$ & $56 \%$ & $0 \%$ & \\
\hline \multirow{2}{*}{$\begin{array}{l}\text { Ability to integrate appropriate } \\
\text { technology }\end{array}$} & 2 & 1 & 1 & 85 & 227 & 0 & 4.68 \\
\hline & $1 \%$ & $0 \%$ & $0 \%$ & $27 \%$ & $72 \%$ & $0 \%$ & \\
\hline \multirow{2}{*}{$\begin{array}{l}\text { Ability to utilize online/Web- } \\
\text { based technologies }\end{array}$} & 2 & 0 & 6 & 74 & 234 & 0 & 4.70 \\
\hline & $1 \%$ & $0 \%$ & $2 \%$ & $23 \%$ & $74 \%$ & $0 \%$ & \\
\hline \multirow{2}{*}{$\begin{array}{l}\text { Ability to create multimedia } \\
\text { digital learning objects }\end{array}$} & 2 & 16 & 90 & 139 & 69 & 0 & 3.81 \\
\hline & $1 \%$ & $5 \%$ & $28 \%$ & $44 \%$ & $22 \%$ & $0 \%$ & \\
\hline \multirow{2}{*}{$\begin{array}{l}\text { Ability to use multimedia } \\
\text { digital learning objects }\end{array}$} & 3 & 4 & 37 & 149 & 122 & 0 & 4.21 \\
\hline & $1 \%$ & $1 \%$ & $12 \%$ & $47 \%$ & $39 \%$ & $0 \%$ & \\
\hline \multirow{2}{*}{$\begin{array}{l}\text { Ability to manage instructional } \\
\text { technologies }\end{array}$} & 1 & 10 & 42 & 127 & 133 & 2 & 4.21 \\
\hline & $0 \%$ & $3 \%$ & $13 \%$ & $40 \%$ & $42 \%$ & $1 \%$ & \\
\hline \multirow{2}{*}{$\begin{array}{l}\text { Ability to train others in use of } \\
\text { instructional technologies }\end{array}$} & 1 & 12 & 53 & 139 & 108 & 0 & 4.09 \\
\hline & $0 \%$ & $4 \%$ & $17 \%$ & $44 \%$ & $35 \%$ & $0 \%$ & \\
\hline \multicolumn{8}{|l|}{ Presentation Skills } \\
\hline \multirow{2}{*}{$\begin{array}{l}\text { Ability to articulate ideas } \\
\text { clearly }\end{array}$} & 2 & 0 & 2 & 17 & 292 & 0 & 4.90 \\
\hline & $1 \%$ & $0 \%$ & $1 \%$ & $5 \%$ & $93 \%$ & $0 \%$ & \\
\hline \multirow{2}{*}{$\begin{array}{l}\text { Ability to present and deliver } \\
\text { content in diverse ways }\end{array}$} & 2 & 1 & 2 & 72 & 235 & 0 & 4.73 \\
\hline & $1 \%$ & $0 \%$ & $1 \%$ & $23 \%$ & $75 \%$ & $0 \%$ & \\
\hline \multirow{2}{*}{$\begin{array}{l}\text { Ability to use classroom } \\
\text { technologies effectively }\end{array}$} & 1 & 1 & 4 & 75 & 231 & 0 & 4.71 \\
\hline & $0 \%$ & $0 \%$ & $1 \%$ & $24 \%$ & $74 \%$ & $0 \%$ & \\
\hline
\end{tabular}




\begin{tabular}{|l|c|c|c|c|c|c|c|c|}
\hline \multicolumn{9}{|c|}{ TABLE 3 (continued) } \\
\hline $\begin{array}{l}\text { Top number is the count of } \\
\text { respondents selecting the } \\
\text { option. Bottom \% is percent } \\
\text { of the total respondents } \\
\text { selecting the option. }\end{array}$ & $\begin{array}{l}\text { strongly } \\
\text { disagree }\end{array}$ & disagree & neutral & agree & $\begin{array}{c}\text { strongly } \\
\text { agree }\end{array}$ & N/A & mean \\
\hline $\begin{array}{l}\text { Ability to effectively use voice, } \\
\text { eye contact, and body language }\end{array}$ & 1 & 1 & 3 & 67 & 240 & 0 & 4.74 \\
\cline { 2 - 10 } & $0 \%$ & $0 \%$ & $1 \%$ & $22 \%$ & $77 \%$ & $0 \%$ & \\
\hline Teaching Skills & & & & & & \\
\hline $\begin{array}{l}\text { Ability to create a learner- } \\
\text { centered teaching environment }\end{array}$ & 2 & 1 & 17 & 113 & 182 & 1 & 4.49 \\
\cline { 2 - 10 } & $1 \%$ & $0 \%$ & $5 \%$ & $36 \%$ & $58 \%$ & $0 \%$ & \\
\hline $\begin{array}{l}\text { Ability to meet student learning } \\
\text { needs (e.g., learning styles) }\end{array}$ & 3 & 0 & 14 & 121 & 178 & 0 & 4.49 \\
\cline { 2 - 11 } & $1 \%$ & $0 \%$ & $4 \%$ & $38 \%$ & $56 \%$ & $0 \%$ & \\
\hline $\begin{array}{l}\text { Ability to provide students } \\
\text { with appropriate feedback/ }\end{array}$ & 3 & 1 & 11 & 110 & 189 & 0 & 4.53 \\
\cline { 2 - 10 } assessment & $1 \%$ & $0 \%$ & $3 \%$ & $35 \%$ & $60 \%$ & $0 \%$ & \\
\hline $\begin{array}{l}\text { Ability to facilitate classroom } \\
\text { communication }\end{array}$ & 1 & 1 & 9 & 87 & 217 & 0 & 4.64 \\
\cline { 2 - 10 } & $0 \%$ & $0 \%$ & $3 \%$ & $27 \%$ & $69 \%$ & $0 \%$ & \\
\hline
\end{tabular}

respondents agreed or strongly agreed and 28 percent selected neutral.

The four presentation skills listed received almost universal agreement as to their importance, with approximately $98 \%-99 \%$ of respondents indicating they agreed or strongly agreed that all the presentation skills were important. Similarly, among the teaching skills listed, 94\%-96\% of respondents agreed or strongly agreed that all four skills were important.

Question five asked respondents to "rank in order (1 least important - 4 most important) the importance of the following knowledge domains to future newly created and/or redefined positions in your library." The mean scores on this scale of 1-4 for the four domains were as follows: teaching skills 3.19; presentation skills 2.84, educational technology skills 2.25; instructional design skills 1.98. See table 4 for details.

\section{Discussion}

In an environment where change is constant and long-standing institutions are no longer able to take for granted their relevance or very existence, academic libraries are challenged to continue to meet their institutions' needs and justify their significance to their administrators, faculty, and students. Today's library administrators play a critical role in funding and approving new or redefined positions. The perceptions (that is to say bias) of high-level library administrators is significant because their associated bias will shape and inform their decisions about funding and approving new or redefined positions to accomplish the library's expanding instructional role. This research study lays the foundation for a discussion of how library administrators view the importance of the selected domains. This in turn can contribute to discussions of how this bias impacts existing and future librarian positions.

\section{Instructional Design Skills}

As discussed in the above survey results, participants had clear preferences when rating the importance of the skill sets associated with instructional design (see table 3). There was consensus by a large majority of administrators (with a mean of 4.58) that the "Ability to define learning outcomes" was a necessary/required skill. This is not terribly surprising given the emphasis in the past decade in higher education to assess the impact of education 
on student learning. Learning outcomes are critical to the instruction process for determining how to gauge and measure students' success in learning.

The "Ability to create a lesson plan" and the "Ability to share with colleagues instructional theories and practices" also scored high: mean 4.42 and a mean of 4.24 respectively. It is interesting that the remaining skills, the "Ability to apply theories of instruction" (a mean of 3.60) and the "Ability to apply theories of learning," (a mean of 3.64) rated the lowest, given the fact that these skills are foundational knowledge for the teaching and learning process. Additionally, respondents did value the "Ability to share with colleagues instructional theories and practices," which could not occur if the position did not already have the required foundational knowledge of the two identified skill sets that scored the lowest in this domain.

\section{Educational Technology Skills}

The attitudes of administrators toward necessary educational technology skills for instruction librarians were biased toward the ability to use (a mean of 4.70), integrate (a mean of 4.68), and adopt (a mean of 4.47) learning technologies as reflected in the report results (see table 3). This bias may be a result of the belief that technology is a key driving force in disruptive change within our profession. Therefore, administrators view these skill sets as vital for librarians to possess in order to keep up with and innovate within the field. The very high mean (4.70) for the librarian's "Ability to utilize online/web-based technologies" may be indicative of the increasing importance of the Internet in the instructional role of the academic library, both with distance education and traditional residential students who are increasingly taking online or hybrid courses at their institutions. It is unclear whether administrators' biases at institutions that place emphasis on online learning would differ significantly from those without such a focus.
In contrast, administrators do not place the same value in librarians" "Ability to manage instructional technologies" with a mean of 4.21 . This finding may well have some interesting implications for how our current administrators view the academic library role within its larger institution. For example, as documented in the past two decades, there has been a trend to merge information technology services and libraries. ${ }^{20}$ In light of this trend, do many library administrators see the management of learning technologies (for example: Learning Management Systems such as Blackboard) outside the area of the librarian?

Administrators clearly do not perceive the librarian's "Ability to create multimedia digital learning objects" as important in relation to the other educational technology skills sets (a mean of 3.81). They do place a slightly higher value on the librarian's "Ability to use multimedia digital learning objects" with a mean of 4.21. These findings are interesting in light of the fact that librarians across the country have been creating hundreds (if not thousands) of library instruction tutorials over the course of the past decade..$^{21}$ The staff labor, time, and costs are not insignificant, and the question arises, does a disconnect exist between library staff and their administrators with regard to the perceived importance of librarians creating these types of resources? Or does this reflect the presence of an entity outside the library available to create online materials?

\section{Presentation Skills}

Administrators agreed in much greater concensus about the necessary skills librarians need in the domain of presentation; therefore, there is less variance within this range $(\mathrm{SD}=.07)$ (see table 3 ). The majority of participants highly value each skill set under presentation. However, the "Ability to articulate ideas clearly" (a mean of 4.9) was the top-rated skill in this group. This result is not surprising, given the fact that it is very difficult to find 
any job postings for instruction librarian positions that do not list good communication skills as an important or necessary component of the position.

\section{Teaching Skills}

Not unlike presentation skills, teaching skills possessed a very small standard deviation (.06) (see table 3). Again, this may be indicative of the near-universal consensus of the high value of the listed skill sets as they relate to the teaching domain. In this category, as in the previous one, one skill set stood slightly apart from the rest. The "Ability to facilitate classroom communication" skill rated the highest with a mean score of 4.64 . The fact that both this category and the previous category ranked communication-related skills as their two highest skills may again be further evidence that today's administrators place a great deal of value in communication skills. Because this domain had the smallest standard deviation of all the surveyed domains, the investigators did not find any significance in the fact that both the "Ability to create a learning centered teaching environment" (mean of 4.49) and the "Ability to meet student learning needs" (mean of 4.49) scored the lowest in the teaching domain.

\section{Ranking the Four Domains}

The final question, as reflected in table 4 , asked participants to rank in order of importance the domains identified in this research study. The results of this question are not equivocal. The administrators had clear opinions as to which are most important. The clear favorite of the four domains was teaching. More than 50 percent of the participants selected this as the most important domain. More than three quarters of the participants gave teaching either a rating of 3 or 4 . As discussed earlier, this domain had the highest mean (at 3.19) of the grouping. The second-highest ranked domain was presentation, with a mean of 2.84 . Only 26 percent of administrators gave this domain the highest ranking of 4 , but more than 70 percent did give it a rating of either 3 or 4 .

These two traditional domains have been a part of the profession for several decades, and the administrators filling out the survey have very positive attitudes toward these domains. This result seems to be consistent with the belief that people are most comfortable with what they are used to and have a great deal of experience with. The two nontraditional domains scored significantly lower with educational technologies receiving a

\section{TABLE 4}

Please Rank in Order (1 Least Important - 4 Most Important) the Importance of the Following Knowledge Domains to Future Newly Created and/or Redefined Positions in Your Library

\begin{tabular}{|l|c|c|c|c|c|}
\hline $\begin{array}{l}\text { Top number is the count of respondents } \\
\text { selecting the option. Bottom \% is } \\
\text { percent of the total respondents } \\
\text { selecting the option. }\end{array}$ & $\mathbf{1}$ & $\mathbf{2}$ & $\mathbf{3}$ & $\mathbf{4}$ & MEAN \\
\hline Instructional design skills & & & & & \\
\hline Educational technology skills & 124 & 77 & 50 & 35 & 1.98 \\
\cline { 2 - 6 } & $43 \%$ & $27 \%$ & $17 \%$ & $12 \%$ & \\
\hline \multirow{2}{*}{ Presentation skills } & 74 & 126 & 55 & 31 & 2.25 \\
\cline { 2 - 6 } & $26 \%$ & $44 \%$ & $19 \%$ & $11 \%$ & \\
\hline Teaching skills & 34 & 47 & 127 & 72 & 2.84 \\
\cline { 2 - 6 } & $12 \%$ & $17 \%$ & $45 \%$ & $26 \%$ & \\
\hline & 37 & 32 & 72 & 167 & 3.19 \\
\cline { 2 - 6 } & $12 \%$ & $10 \%$ & $23 \%$ & $54 \%$ & \\
\hline
\end{tabular}


mean score of 2.25. The educational technologies domain had only 11 percent of survey participants give it the top score, and not even a third (30\%) of participants gave it either a score of 3 or 4 . The lowest scoring domain (instructional design skills) received a mean score of only 1.98 . The instructional design domain had 43 percent of administrators select it as the least important of the domains. Nearly three quarters $(70 \%)$ of respondents gave this domain a rating of either 1 or 2 .

These results raise some thoughtprovoking questions. The teaching domain focuses more on classroom-based instruction skills. It is well documented how librarians struggle with increasing the relatively small amount of in-class time that faculty provide to meet with their students. In contrast, instructional design focuses more on the design and development of either an instructional process or product. This skill set facilitates the development of instruction not only in the classroom but also outside the classroom. As instruction increasingly moves online in a hybrid or online course format, it would seem that traditional classroombased teaching skills will play a less significant role than instructional design skills. Furthermore, from the results there appears to be an inverse relationship between teaching and instructional design domains in the eyes of the administrators. This is somewhat surprising given the fact that instructional design skills are based on the foundations of cognitive learning theories and instructional strategies. But this may be reflective of a perception that instructional design implies online instructional design.

Surprisingly, educational technologies scored below presentation. Despite all the literature about how our profession has been impacted by technological changes and has adopted more and more information technology skill sets, it appears that administrators currently do not view educational technologies as critical to the education mission of the library. Yet, the literature is replete with articles discussing new Web 2.0 technologies that libraries are investigating or using to offer a new and innovative service for their institutions.

Could it be that academic library administrators, presumably having left frontline public services positions (or even technical services positions) at some point in the past, are not as aware of the relatively recent adoption of instructional design and educational technology skills by librarians seeking to extend their proficiencies in instruction? If this is the case, could it be that they are unfamiliar with the terminology related to the new skill sets and this ignorance contributes to the low rankings? Could it be that librarians involved in instruction will need to be the prime movers of change, rather than their administrators?

\section{Future Directions}

Moving forward, the investigators plan to examine the data from this survey further to see if there are relationships between gender and attitudes toward the four domains. Moreover, the relationship between the number of years within the profession and the administrators' perceptions will be examined. Finally, does the bias of the administrator differ depending on the institutional size and type?

Additional research could be conducted to investigate whether the existence of a unit that creates multimedia digital learning objects internal or external to a library affects library administrators' rankings of the skills associated with educational technology. The results of this study also raise concerns as to the treatment of librarians whose positions require the use of instructional design and educational technology. Future research can examine whether they are understood, appreciated, or discriminated against. Are they treated differently from colleagues with more traditional skill sets? Finally, the existence of new job titles and position descriptions raises the question of whether the terms used are simply "trendy" or used to satisfy 
higher administrators who are unwilling to fund another "reference librarian." Do library administrators fully understand the proper definitions of the terms used?

\section{Conclusion}

The researchers sought to measure the perceptions of today's library administrators toward the selected domains to begin to better understand the biases of the people in critical positions both within their institutions and within the profession. Library administrators have the power to greatly influence and determine staffing and funding issues in higher education, and so their biases will impact change within our profession. The investigators in this study understood that, before the profession can gauge the impact of library administrators' biases, it is vital to measure what those biases may be. This survey instrument accomplished the goal of providing baseline data that can be used to begin to understand how current administrator perceptions are impacting change within the profession.

As reflected in the survey results, administrators clearly rate the traditional skills associated with presentation and teaching higher than the newly emerging instructional design and educational technology skill sets. The reasons for this are not entirely clear, and this survey did not attempt to answer that question. However, it is possible that it is as a result of the fact that current administrators are more comfortable with the traditional skills. If this is the case, there are profound implications for the profession. Are newly developing domains that could be critical for our profession's ability to innovate and remain relevant to future generations being potentially stymied by the biases of library administrators?

The profession is in the midst of an unprecedented paradigm shift, moving from print-based to digital-based information. This dramatic change is impacting, and will continue to impact, the academic library. Clearly, it is vital to have highly skilled employees who are able to rapidly adapt to the changes as well as drive the innovations within the field. This study raises a very big question: who is responsible for driving that process? If, as the authors suppose, library administrators are key players in facilitating the hiring of new or redefined positions, then, based on the survey data, library administrators might be restraining change within the educational role of the library because of their biases. Does this mean that mid-level managers or public services librarians who see a need for advanced skill sets to move forward with instructional needs of the library will drive this change, despite possible lack of support from their supervisors? Future studies will need to further explore these questions, and today's administrators will need to look within themselves to discover if their biases are hindering or facilitating the adoption of skills that may indeed be vital to the relevance, impact, and ultimately the very existence of the academic library in higher education. 


\section{Appendix A \\ Library Administrators' Perceptions of Critical Skills Needed for the Instructional Process}

\section{Heading}

When thinking about the necessary or required skills for librarians who participate in the library's instructional process, please rate the importance on a scale of 1 (strongly disagree) to 5 (strongly agree) for each of the following:

\section{Question 1 - Rating Scale - Matrix}

\begin{tabular}{|c|c|c|c|c|c|c|}
\hline \multicolumn{7}{|l|}{ Instructional design skills: } \\
\hline & $\begin{array}{l}\text { strongly } \\
\text { disagree }\end{array}$ & disagree & neutral & agree & $\begin{array}{c}\text { strongly } \\
\text { agree }\end{array}$ & N/A \\
\hline \multicolumn{7}{|l|}{ Ability to define learning outcomes } \\
\hline \multicolumn{7}{|l|}{ Ability to create a lesson plan } \\
\hline \multicolumn{7}{|l|}{$\begin{array}{l}\text { Ability to apply theories of } \\
\text { instruction (e.g., Gagne's Nine } \\
\text { Events of Instruction) }\end{array}$} \\
\hline \multicolumn{7}{|l|}{$\begin{array}{l}\text { Ability to apply theories of learning } \\
\text { (e.g., Behaviorism, Cognitvism, } \\
\text { Constructivism) }\end{array}$} \\
\hline $\begin{array}{l}\text { Ability to share with colleagues } \\
\text { instructional theories and practices }\end{array}$ & & & & & & \\
\hline
\end{tabular}

\section{Question 2 - Rating Scale - Matrix}

\begin{tabular}{|c|c|c|c|c|c|c|}
\hline \multicolumn{7}{|l|}{ Educational technology skills: } \\
\hline & $\begin{array}{l}\text { strongly } \\
\text { disagree }\end{array}$ & disagree & neutral & agree & $\begin{array}{l}\text { strongly } \\
\text { agree }\end{array}$ & N/A \\
\hline \multicolumn{7}{|c|}{$\begin{array}{l}\text { Ability to adopt emerging } \\
\text { instructional technologies (e.g., Web } \\
2.0 \text { ) }\end{array}$} \\
\hline \multicolumn{7}{|l|}{$\begin{array}{l}\text { Ability to integrate appropriate } \\
\text { technology }\end{array}$} \\
\hline \multicolumn{7}{|l|}{$\begin{array}{l}\text { Ability to utilize online/web-based } \\
\text { technologies }\end{array}$} \\
\hline \multicolumn{7}{|l|}{$\begin{array}{l}\text { Ability to create multimedia digital } \\
\text { learning objects }\end{array}$} \\
\hline \multicolumn{7}{|l|}{$\begin{array}{l}\text { Ability to use multimedia digital } \\
\text { learning objects }\end{array}$} \\
\hline \multicolumn{7}{|l|}{$\begin{array}{l}\text { Ability to manage instructional } \\
\text { technologies }\end{array}$} \\
\hline $\begin{array}{l}\text { Ability to train others in use of } \\
\text { instructional technologies }\end{array}$ & & & & & & \\
\hline
\end{tabular}




\section{Question 3 - Rating Scale - Matrix}

\begin{tabular}{|c|c|c|c|c|c|c|}
\hline \multicolumn{7}{|l|}{ Presentation skills: } \\
\hline & $\begin{array}{l}\text { strongly } \\
\text { disagree }\end{array}$ & disagree & neutral & agree & $\begin{array}{c}\text { strongly } \\
\text { agree }\end{array}$ & N/A \\
\hline \multicolumn{7}{|l|}{ Ability to articulate ideas clearly } \\
\hline \multicolumn{7}{|l|}{$\begin{array}{l}\text { Ability to present and deliver } \\
\text { content in diverse ways }\end{array}$} \\
\hline \multicolumn{7}{|l|}{$\begin{array}{l}\text { Ability to use classroom } \\
\text { technologies effectively }\end{array}$} \\
\hline $\begin{array}{l}\text { Ability to effectively use voice, } \\
\text { eye contact, and body language }\end{array}$ & & & & & & \\
\hline
\end{tabular}

\section{Question 4 - Rating Scale - Matrix}

\begin{tabular}{|l|l|l|l|l|l|l|}
\hline Teaching skills: & & & & & & \\
\hline & $\begin{array}{c}\text { strongly } \\
\text { disagree }\end{array}$ & disagree & neutral & agree & $\begin{array}{c}\text { strongly } \\
\text { agree }\end{array}$ & N/A \\
\hline $\begin{array}{l}\text { Ability to create a learner-centered } \\
\text { teaching environment }\end{array}$ & & & & & & \\
\hline $\begin{array}{l}\text { Ability to meet student learning } \\
\text { needs (e.g., learning styles) }\end{array}$ & & & & & & \\
\hline $\begin{array}{l}\text { Ability to provide students with } \\
\text { appropriate feedback/assessment }\end{array}$ & & & & & & \\
\hline $\begin{array}{l}\text { Ability to facilitate classroom } \\
\text { communication }\end{array}$ & & & & & & \\
\hline
\end{tabular}

\section{Question 5 - Ranking Question}

Please rank in order (1 least important - 4 most important) the importance of the following knowledge domains to future newly created and/or redefined positions in your library.

\begin{tabular}{|l|l|l|l|l|}
\hline & $\mathbf{1}$ & $\mathbf{2}$ & $\mathbf{3}$ & $\mathbf{4}$ \\
\hline Instructional design skills & & & & \\
\hline Educational technology skills & & & & \\
\hline Presentation skills & & & & \\
\hline Teaching skills & & & & \\
\hline
\end{tabular}

\section{Question 6 - Open Ended}

What additional skill sets related to these domains would you consider critical to your library's instructional process?

\begin{tabular}{|l|l|}
\hline Instructional design skills: & \\
\hline Educational technology skills: & \\
\hline Presentation skills: & \\
\hline Teaching skills: & \\
\hline
\end{tabular}




\title{
Question 7 - Open Ended
}

Please list the name of your institution:

\section{Question 8 - Open Ended}

Please list your position title:

\section{Question 9 - Open Ended}

How many years have you worked as a librarian?

\author{
Question 10 - Choice \\ What is your gender? \\ $\square$ Male \\ $\square$ Female
}

\section{Question 11 - Open Ended - Comments Box}

Please list any additional comments.

\section{Notes}

1. Association of College and Research Libraries Research Committee, "Environmental Scan 2007," ACRL, available online at www.ala.org/ala/mgrps/divs/acrl/publications/whitepapers/ Environmental_Scan_2007 FINAL.pdf [accessed 24 June 2010].

2. Ibid., 4 .

3. Steven J. Bell and John Shank, “The Blended Librarian," Learning Times, available online at blendedlibrarian.org [accessed 10 December 2010].

4. Association of College and Research Libraries, "ACRL Standards for Proficiencies for Instruction Librarians and Coordinators," ACRL, available online at www.ala.org/ala/mgrps/ divs/acrl/standards/profstandards.cfm [accessed 24 June 2010].

5. Thomas G. Kirk, "Bibliographic Instruction, Library Education, and the Role of the Academic Librarian," in Russian-American Seminar on Critical Thinking and the Library: Papers from the Seminar, Moscow, June 1-5, 1992, eds. Cerise Oberman and Dennis Kimmage, 97-112 (Champaign, Ill.: Graduate School of Library and Information Science, University of Illinois at Urbana-Champaign, 1995), available online at www.ideals.illinois.edu/bitstream/handle/2142/3832/gslisoccasionalpv00000i200_1.pdf?sequence=1 [accessed 9 December 2010]; Heidi Julien, "Education for Information Literacy Instruction: A Global Perspective," Journal of Education for Library and Information Science 46 (Summer 2005): 210-16, available online at www.jstor.org/stable/40323845 [accessed 12 July 2010]; Claudeen Sproles, Anna Marie Johnson, and Leslie Farison, "What the Teachers Are Teaching: How MLIS Programs Are Preparing Academic Librarians for Instructional Roles," Journal of Education for Library \& Information Science 49 (Summer 2008): 195-209.

6. Stephen Pinfield, "The Changing Role of Subject Librarians in Academic Libraries," Journal of Librarianship and Information Science 33 (2001): 32-38.

7. Janice Simmons-Welburn, Association of Research Libraries, and Office of Leadership and Management Services, Changing Roles of Library Professionals: SPEC Kit 256 (Washington, D.C.: Association of Research Libraries, 2000), 75, 79, 82, available online at www.eric.ed.gov/PDFS/ ED443440.pdf [accessed 29 July 2010].

8. Pinfield, "Changing Role"; and Simmons-Welburn, Changing Roles.

9. Simmons-Welburn, Changing Roles; Lisa Allen, "Hybrid Librarians in the 21st Century Library: A Collaborative Service-Staffing Model" (paper presented at ACRL Twelfth National Conference, Minneapolis, Minn., April 7-10, 2005), available online at http://www.ala.org/acrl/ sites/ala.org.acrl/files/content/conferences/pdf/allen05.pdf [accessed 19 December 2011]; Lori A. Goetsch, "Reinventing Our Work: New and Emerging Roles for Academic Librarians," Journal of Library Administration 48 (2008): 157-72, doi:10.1080/01930820802231351.

10. Simmons-Welburn, Changing Roles; Allen, "Hybrid Librarians"; Goetsch, "Reinventing Our Work"; John Shank, "The Blended Librarian: A Job Announcement Analysis of the Newly 
Emerging Position of Instructional Design Librarian," College E Research Libraries 67 (Nov. 2006): 514-24.

11. Tai Phan, Laura Hardesty, Cindy Sheckells, and Denise Davis, "Academic Libraries: 2008," NCES 2010-348, Washington, D.C.: National Center for Education Statistics, Institute of Education Sciences, U.S. Department of Education (2009), available online at http://nces.ed.gov/ pubs2010/2010348.pdf [accessed 29 July 2010].

12. U.S. Department of Education, Institute of Education Sciences, National Center for Education Statistics, "Search for Schools, Colleges, and Libraries," NCES, available online at http://nces. ed.gov/globallocator/ [accessed 13 December 2010].

13. International Federation of Library Associations and Institutions (IFLA), "LibJobs Library and Information Science Jobs Mailing List," IFLA, available online at http://infoserv.inist.fr/ wwsympa.fcgi/subrequest/libjobs [accessed 25 June 2010].

14. Educause, "Job Opportunities," Educause, available online at www.educause.edu/ jobs?tid=16500 [accessed 13 December 2010].

15. American Library Association, "ALA JobLIST," ALA, available online at http://joblist.ala. org/ [accessed 24 June 2010].

16. University of Texas at Austin, "IAR Instructional Assessment Resources: Assess Teaching > Response Rates," University of Texas at Austin, available online at www.utexas.edu/ academic/diia/assessment/iar/teaching/gather/method/survey-Response.php [accessed 29 July 2010].

17. Mary J. Lynch and American Library Association Office for Research and Statistics, "Library Directors: Gender and Salary [1999]," American Library Association, available online at www. ala.org/ala/research/librarystaffstats/diversity/libdirectors.cfm [accessed 12 July 2010].

18. Association of Research Libraries, "ARL Annual Salary Survey 2009-2010," ARL, available online at www.arl.org/stats/annualsurveys/salary/sal0910.shtml [accessed 12 July 2010].

19. Carnegie Foundation for the Advancement of Teaching, "Carnegie Classifications," Carnegie Foundation for the Advancement of Teaching, available online at http://classifications. carnegiefoundation.org/ [accessed 15 July 2010].

20. Richard M. Dougherty, "Libraries and Computing Centers: A Blueprint for Collaboration," College E Research Libraries 48 (July 1987): 289-96; Steven J. Herro, "Impact of Merging Academic Libraries and Computer Centers on User Services" (master's thesis, Minnesota State University, Mankato, 1998), available online at http://net.educause.edu/ir/library/pdf/CSD1193.pdf [accessed 19 August 2010]; Books, Bytes, and Bridges: Libraries and Computer Centers in Academic Institutions, ed. Larry Hardesty (Chicago: American Library Association, 2000).

21. See "A.N.T.S.: ANimated Tutorial Sharing Project," available online at http://ants.wetpaint. com/ [accessed 13 December 2010]; and ACRL Instruction Section, "PRIMO: Peer-Reviewed Instructional Materials Online," available online at www.acrl.org/apps/primo/public/search.cfm [accessed 13 December 2010]. 